\title{
PERSEPSI MASYARAKAT ADAT KAMPUNG CIKONDANG DAN CIREUNDEU DALAM MEMAKNAI NILAI-NILAI KARAKTER BAGI SEORANG PEMIMPIN
}

Oleh:

Trisna Sukmayadi

Universitas Ahmad Dahlan Yogyakarta

e-mail: trisnasukmayadi@ppkn.uad.ac.id

\section{Suyitno}

Universitas Ahmad Dahlan Yogyakarta

\begin{abstract}
ABSTRAK
Tujuan dari penelitian ini adalah untuk mengungkap persepsi masyarakat adat Kampung Cireundeu Kota Cimahi dan Cikondang Kabupaten Bandung dalam memaknai nilai-nilai karakter yang harus dipunyai oleh seorang pemimpin. Pendektan penelitian menggunakan kualitatif dengan jenis studi kasus. Teknik analisis data melalui studi liratur, wawancara mendalam, dan observasi, setelah dianalisis, kemudian dicocokan kebenarannya melalui triangulasi. Hasil penelitian menunjukan secara umum masyarakat adat berpersepsi bahwa nilai-nilai karakter yang harus dimiliki oleh seorang pemimpin di masyarakat adat Kampung Cireundeu dan Cikondang adalah nilai karakter religius, taat kepada adat dan tradisi leluhur, dan taat pada falsafah sunda, yakni silih asih, silih asah, dan silih asuh. Makna nilai-nilai karakter tersebut bagi masyarakat adat kampung Cireundeu dan Cikondang, yakni sebagai fondasi dalam membangun kehidupan masyarakat sesuai adat dan tradisi leluhur
\end{abstract}

Kata kunci: Persepsi, Masyarakat adat, Nilai Karakter

\section{PENDAHULUAN}

Keberadaan seorang pemimpin merupakan bagian yang tidak terpisahkan dari keberhasilan suatu organisasi, yakni pemimpin yang mampu memimpin anggotanya dalam segala bidang, artinya seorang pemimpin dianggap sebagai orang yang segala tahu dan segala bisa. Hal ini senada dengan yang dijelaskan oleh Marpaung, M (2014), bahwa ternyata gaya kepemimpinan akan sangat berpengruh terhadap cara kerja anggotanya/pegawainya, hal ini disebabkan karena kinerja anggota yang baik baik, kecenderungannya akan melakukan kerja tim yang baik pula. Jikalau hal tersebut diimplemetasikan dalam kepimpinan di masyarakat, maka pemimpin yang 
baik, cenderung dapat diikuti oleh segenap warga masyarakatnya.

Pemimpin dalam

melaksanakan kewajibannya harus bersift bijak. Seperti yang dijelaskan oleh Wahjosumidjo (1999), bahwa seorang pemimpin harus mempunyai kedewasaan dan kecerdasan dalam berfikir. Pendapat ini memberikan penegasan bahwa seorang pemimpin harus bisa berbuat bijak dan berfikir cerdas dalam menghadapi segala persoalan.

Konsep kepemimpinan masa kini sekurang-kurangnya dapat dibedakan menjadi dua bentuk, yakni kepemimpinan modern dan tradisional. Perihal ini, sesuai dengan apa yang dijelaskan oleh Fatimah, S (2011) bahwa pola-pola kepemimpinan tidak terlepas dari faktor kondisi sosial budaya, sistem nilai, status sosial, dan agama atau kepercayaan yang ada di masyarakat. Penjelasan dari pendapat ini adalah kepemimpinan modern dapat diartikan sebagai kepemimpinan yang sudah ada pembaharuan sesuai dengan perkembangan jaman, sedangkan kepemimpinan tradisional merupakan kepemimpinan yang masih mempertahankan nilai-nilai luhur para leluhurnya. Selain itu, dapat dijelaskan pula bahwa kosnep kepemimpinan dapat dipengaruhi oleh persepsi warga masyarakatnya terhadap makna seorang pemimpin.

$$
\text { Pergeseran persepsi }
$$

masyarakat terhadap makna pemimpin dan memicu pergeseran kepemimpinan. Misalnya, saat ini masyarakat berpersepsi tentang demokrasi maka kepemimpinannyapun akan menyesuaikan dengan konsep demokrasi. Begitu pula pada kepemimpinan tradisional, meskipun sekarang sudah masa demokrasi, namun masyarakatnya masih berpersepsi tentang amanat para leluhurnya, maka konsep kepemimpinannya pun akan sesuai dengan amanat para leluhurnya. Maka berdasar pada hal ini, betapa pentingnya persepsi tentang makna seorang pemimpin dalam melahirkan seorang pemimpin yang baik dan harapkan oleh masyarakatnya. Hal ini senada dengan pendapat Sondang P Siagian (2011) bahwa persepsi adalah hasil penerjemehan manusia terhadap segala hal dalam lingkungannya yang berupa kesankesan. Jadi persepsi dalam tinjauan psikologis adalah cara pandang manusia dalam merespon suatu gejala lingkungan yang ada. Oleh karena itu persepsi untuk kepemimpinan tradisional

Kepemimpinan berdasarkan nilai-nilai kearifan lokal termasuk pada bentuk kepemimpinan tradisional, yang pada dasarnya merupakan hal yang sangat menarik untuk diteliti, ditelaah, dan dikaji, karena terdapat nilai-nilai yang dapat memungkinkan masyarakatnya patuh pada pemimpin dan nyaman sebagai 
yang dipimpin. Sebenarnya, studi tentang kearifan lokal ternyata telah ada dari sejak penelitian-penelitian terdahulu, antara lain Sukmayadi, T (2016), Ruyadi, Y (2010), dan Elfira, M (2013). Namun studi tersebut masih bersifat umum yakni tentang nilai-nilai kearifan lokal, tidak mengkhususkan pada pengkajian tentang persepsi masyarakat adat tentang makna pemimpin.

Studi yang dilakukan oleh Sukmayadi, T (2016), sebagian hasilnya menunjukan bahwa masyarakat adat Kampung Kuta berpersepsi bahwa kearifan lokal merupakan warisan budaya bangsa sebagai nilai yang luhur, yang diwariskan oleh leluhur/karuhun sebagai pembentukan identitas dan jati diri yang wajib untuk dijaga dan dilestarikan. Oleh karenanya nilainilai kearifan lokal menjadi persepsi hidup dalam menjalani kehidupan. Studi berikutnya dilakukan oleh Ruyadi, Y (2010), hasil dari penelitian ini menunjukan bahwa masyarakat adat Kampung Benda Kerep Cirebon memiliki pola pendidikan yang cukup efektif dalam mewariskan nilai-nilai budi pekerti kepada generasi berikutnya. Sehingga persepsi pendidikannya berpola pada adat dan tradisi para leluhur. Selanjutnya penelitian yang dilakukan oleh Elfira, M (2013), sebagian hasil penelitiannya menunjukan bahwa model kepemimpinan di Minangkabau dan Bugis dapat digunakan untuk penataan organisasi modern. Dapat diartikan bahwa organisasi modern atau kepemimpinan modern saat ini dapat mengadopsi kepemimpinan berbasis nilai-nilai kearifan lokal.

Adanya ketimpangan antara pemimpin yang dicita-citakan dengan realitas kepemimpinan saat ini, menjadikan adanya masalah krisis kepemimpinan yaitu dengan melemahnya nilai-nilai karakter yang ada pada jiwa-jiwa seorang pemimpin, salah satunya adalah perilaku korupsi. Krisis ini tentunya mengakibatkan roda pemerintahan terganggu. Lain halnya dengan masyarakat adat, sepanjang penelurusan tentang kepemimpinan adat, belum menemukan adanya pemimpin yang megkhianati amanah rakyat dengan melakukan tindakan korupsi, dan lain sebagainya.

Perihal tentang korupsi, berdasarkan sumber ICW (Atriana, R. 2016), kasus korupsi di Indonesia sejak periode Januari 2016 hingga Juni 2016 terdapat sebanyak 210 kasus ditangani dan 500 orang ditetapkan sebagai tersangka oleh 3 institusi penegak hukum. Sepanjang semester I 2016, aparat penegak hukum berhasil menaikkan status kasus dari penyelidikan ke penyidikan sebanyak 210 kasus di mana kerugian negara mencapai $\mathrm{Rp}$ 890,5 miliar dan suap Rp 28 miliar, SGD 1,6 juta, dan USD 72 ribu. Korupsi tengah merajalela di republik ini, seperti gelombang laut yang tiada berhenti setiap harinya. 
Negara telah banyak dirugikan, dan rakyat disengsarakan akibat korupsi yang dilakukan oleh oknum pemimpin atau pejabat negara.

Jikalau dikaji dalam sudut pandang karakter seorang pemimpin, sesungguhnya hal ini bertolak belakang dengan kepemimpinan warisan leluhur bangsa Indonesia. Di Indonesia dikenal beberapa jenis pemimpin yaitu pemimpin adat, pemimpin pemerintah, pemimpin agama, pemimpin pendidikan, pemimpin politik dan berbagai pemimpin lainnya. Kepemimpinan dalam masyarakat adat dikategorikan sebagai pemimpin informal, dimana dia mencapai kedudukan sebagai seorang pemimpin melalui aturan adat yang berlaku dalam masyarakatnya, biasanya berdasarkan garis keturunan para leluhurnya. Hal ini masih dapat kita saksikan keberadaannya dalam kepemimpinan masyarakat adat di Indonesia, salah satuya adalam pada masyarakat adat Kampung Cireundeu Kota Cimahi dan Kampung Cikondang Kabupaten Bandung. Masyarakat adat merupakan masyarakat yang masih memegang teguh tradisi dan nilai budaya warisan leluhurnya ditengah himpitan era globalisasi dan modernisasi.

Kepemimpinan pada masyarakat adat tidak terlepas dari persepsi masyarakatnya terhadap makna pemimpin, sehingga menjadikan pemimpin di masyarakat adat diingini, dihormati, dan disegani. Oleh karenanya, penting sekali untuk meninjau kembali tentang persepsi masyarakat adat terhadap makna pemimpin.

\section{METODE}

Penelitian ini menggunakan pendekatan kualitatif, yakni penelitian yang pada dasarnya membutuhkan data lapangan yang aktual dan konstektual sesuai dengan latar alamiahnya. Seperti halnya dikemukakan oleh Creswell (Satori, D dan Aan Komariah, 2011: 24) bahwa penelitian kualitatif pada dasarnya meneliti tentang pemahaman yang mendasarkan pada tradisi metodologis terpisah tentang masalah sosial atau manusia yang dikaji secara mendalam. Pada penelitian ini, masalah didasarkan pada persepsi masyarakat adat dalam memaknai pemimpin sehingga mereka mempunyai pemimpin yang diinginkan dan disegani, sesuai dengan harapan masyarakat. Jenis penelitian yang digunakan adalah studi kasus. Menurut Maxfield (Nazir, 2005: 57), bahwa studi kasus adalah penelitian tentang status subjek penelitian yang berkenan dengan suatu fase spesifik atau khas dari keseluruhan personalitas. $\mathrm{Ke}$ khasan dalam penelitian ini adalah tentang kepemimpinan berbasiskan nilai-nilai kearifan lokal, yakni pada masyarakat adat. 
Penelitian ini berlokasi di lingkungan masyarakat adat Kampung Cireundeu Kota Cimahi dan Kampung Cikondang Kabupaten Bandung, Provinsi Jawa Barat, dengan sasaran penelitian ketua adat, tokoh masyarakat, dan masyarakat Kampung Cireunde dan Cikondang.

Teknik pengumpulan data dilakukan dengan menggunakan 1) studi literatur terhadap konsep persepsi, kepemimpinan, dan kearifan lokal; 2) wawancara mendalam kepada ketua, tokoh, dan masyarakat adat; dan 3) observasi dilakukan pada lingkungan masyarakat adat. Pelaksanaan penelitian ini dilakukan dalam tiga tahapan, yakni tahap orientasi, tahap eksplorasi dan tahap member-check

\section{HASIL DAN PEMBAHASAN}

Secara umum, masyarakat berpersepsi bahwa nilai-nilai karakter yang harus dimiliki oleh seorang pemimpin di masyarakat adat Kampung Cireundeu dan Cikondang adalah nilai karakter religius, taat kepada adat dan tradisi leluhur, dan taat pada falsafah sunda, yakni silih asih, silih asah, dan silih asuh.

Pertanyaan pertama yang muncul adalah apa itu persepsi sehingga penting untuk dipelajari? Perihal persepsi ini, seringkali tidak dianggap menjadi hal yang luar biasa dalam merumuskan dan menetukan sesuatu, padahal jikalau ditinjau dari kajian etimologis dan faktor penyebab persepsi itu ada, tentunya persepsi ini akan sangat penting unuk dikaji terlebih dahulu. Berdasarkan Kamus Besar Bahasa Indonesia (KBBI) dalam jaringan, persepsi mempunyai dua makna, yakni tanggapan (penerimaan) langsung dari sesuatu, dan proses seseorang mengetahui beberapa hal melalui pancaindranya. Maka dalam kajian ini dapat dianalisis bahwa persepsi merupakan pandangan manusia terhadap hal-hal melalui pancaindranya. Dan berdasarkan pandangan-pandangan inilah dengan sendirinya akan membentuk kebiasaan.

Selanjutnya, Asrori, M (2009) juga menjelaskan bahwa didalam persepsi terdapat suatu proses pemberian makna terhadap semua stimulus dari lingkungan dimana dia berada melalui interpretasi dan pengorganisasian dalam pengalaman-pengalaman tertentu juga merupakan hasil belajar manusia terhadap fenomena tertentu. Pengertian tersebut mempunyai dua makna yang harus dijelaskan, yakni interpetasi dan pengorganisasian. Interpetasi dalam KBBI daring mempunyai pengertian pemberian kesan, pendapat, pandangan teoretis terhadap sesuatu, atau tafsiran. Sedangkan pengorganisasian adalah proses, cara, atau perbuatan untuk mengorganisasi. Jadi di dalam mempersepsi, seorang manusia melalukan tafsiran-tafsiran secara teratur atau terorganisasi yang 
dibentuk dalam waktu yang lama sehingga menjadi pola pikir yang matang. Begitupun dengan persepsi masyarakat adat Kampung Cikondang dan Cireundeu, persepsinya telah dibentuk dalam kurun waktu yang lama, yakni sejak ada nenek moyangnya. Persepsi tersebut membentuk pola pikir masyarakat adat menjadi matang dalam hal kepemimpinan dalam kelompoknya. Artinya mereka tahu betul pemimpin yang seperti apa yang amanah dan tidak berkhianat untuk diri dan kelompoknya.

Lain halnya dengan Slameto (2010), yang menjelsakan bahwa dildalam persepsi terdapat pesan yang masuk kedalam pikiran manusia hasil dari interaksi dengan lingkungannya. Disini dapat dijelaskan tentang adanya suatu pesan, yakni segala sesuatu yang tertangkap oleh pancaindera manusia dari hasil interaksi dengan lingkungannya yang membentuk suatu konsep. Konsep inilah yang akan melahirkan suatu tafsirantafsiran atas pencermatan dari konsep-konsep tersebut. Pesan yang ditangkap oleh masyarakat adat Kampung Cikondang dan Cireundeu adalah pesan tentang kepemimpinan yang bak bagi diri dan kelompoknya sehingga terbentuk suatu konsep kepemimpinan yang baik.

Pertanyaan kedua adalah faktor apa saja yang mempengaruhi persepsi sehingga persepsi dianggap penting untuk dipelajari? Perihal ini, sebagaimana yang dijelaskan oleh Thoha, M (2005), bahwa faktor yang mempengaruhi terjadinya persepsi dalam diri manusia adalah adanya faktor internal, yakni munculnya perasaan, adanya perhatian terhadap sesuatu, tingkat kepribadian individu, sikap, tingkat kebutuhan, motivasi untuk mengetahui, dan keadaan fisik. Selain faktor internal tersebut, juga terdapat faktor eksternal, yakni pengetahuan dan kebutuhan sekitar, latar belakang pribadi dan keluarga, serta informasi yang diperoleh terhadap seuatu hal.

Persepsi pada masyarakat adat Kampung Cireundeu dan Cikondang jikalau ditinjau dari faktor-faktor penyebab terjadinya persepsi, dapat terlihat faktor yang paling utamanya adalah lingkungan. Lingkunganlah yang membentuk pemikiran sehingga terkonstruk sebuah persepsi. Lingkungan masyarakat adat yang damai, tenteram, penuh cinta kasih, dan berserah diri pada Tuhan Yang Maha Kuasa, membuat pemikiran mereka bersih dari hal-hal negatif, sehingga bersih pula persepsinya.

$$
\text { Perihal faktor-faktor }
$$
penyebab terjadinya perspsi, Robins, S.P (1996) menjelaskan bahwa ada tiga faktor yang mempengaruhi persepsi seseorang. Pertama, adanya individu yang mempersepsi. Keberadaan individu dalam mempersepsi sangat penting, karena 
di dalam individu terdapat pola pikir yang siap menerima bentukan dari lingkungannya. Begitu juga pola pikir masyarakat adat Kampung Cikondang dan Cireundeu yang mengutamakan keserasian dan kedamaian dalam hidup. Oleh karena itu terjemahan pola pokirnya juga akan menterjemahkan pola hidup yang serasi dan damai. Kedua, adanya sasaran dari persepsi yang dituju. Sasaran yang dimaksud oleh masyarakat adat Kampung Cikondang dan Cirendeu adalah tentang keberadaan seorang pemimpin yang baik bagi kelompoknya. Oleh karena itu atas dasar sasaran inilah mereke berpersepsi dengan begitu baik, karena demi kebaikan diri dan kelompoknya. Ketiga, dalam mempersepsi adanya situasi. Situasi yang dimaksud adalah keadaan yang sesungguhnya dalam suatu lingkungan. Dimana di dalam situasi tersebut terdapat pola teratur yang diatur oleh norma-norma yang berlaku di daerah tersebut. Seperti pada masyarakat adat Kampung Cikondang dan Cireundeu, situasi disana begitu teratur karena keteraturan tersebut dibentuk oleh norma-norma yang sampai saat ini mereka patuhi. Situasi inilah yang membentuk persepsi mereka terhadap kepemimpinan yang baik bagi diri dan kelompoknya.

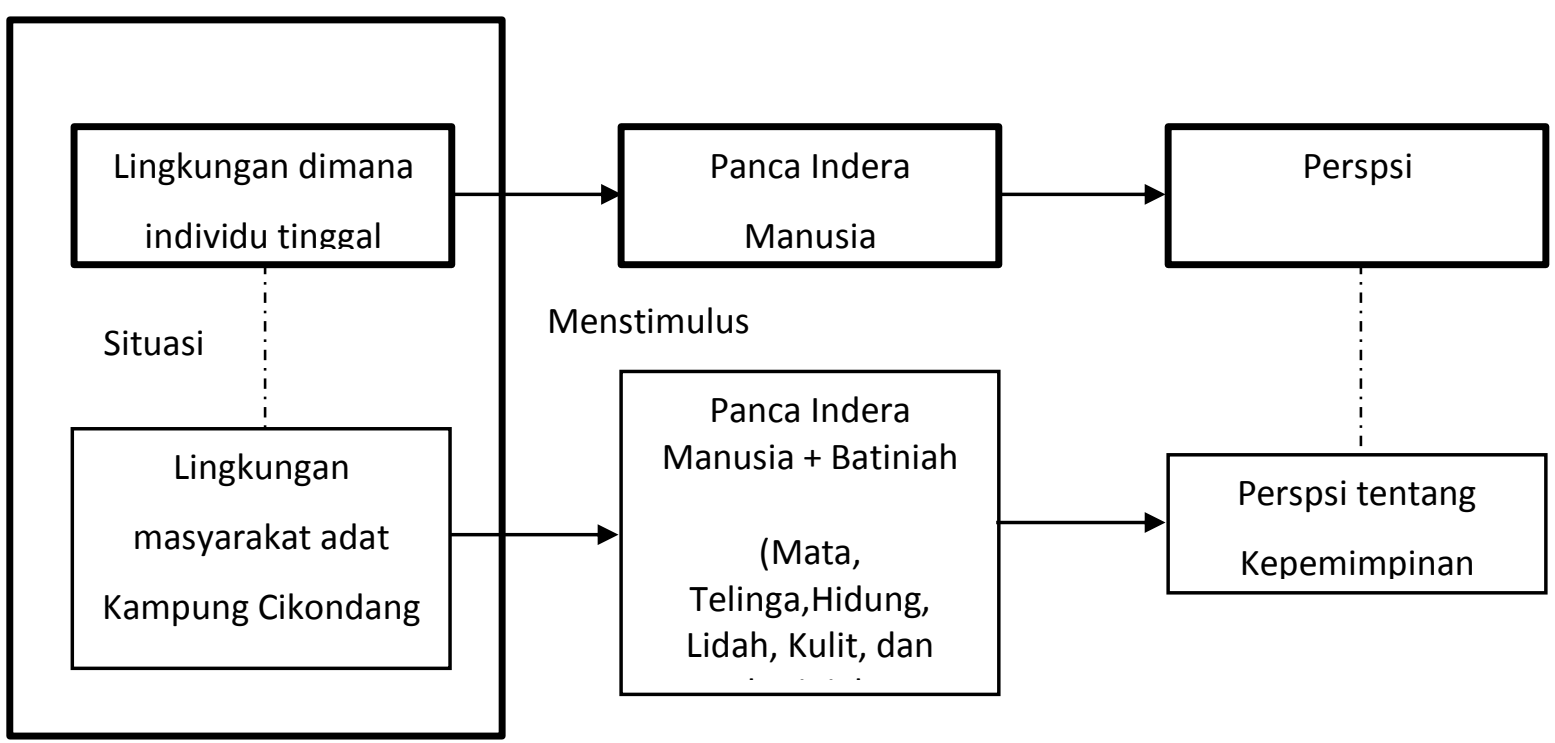

Gambar 1. Proses terjadinya Persepsi pada masyarakat adat Kampung Cikondang dan Cireundeu

Berdasarkan pada persepsi masyarakat terkait nilai-nilai karakter yang harus dimiliki oleh seorang pemimpin di masyarakat adat
Kampung Cikondang dan Cireundeu, ternyata nilai religius merupakan pandangan hidup yang paling utama bagi seorang pemimpin. Nilai 
religius ini bermakna sebagai penyerahan diri manusia kepada Tuhan-Nya dalam bentuk pengabdian. Jadi menjadi pemimpin pada masyarakat adat bukan hanya sekedar melayani masyrakatnya, akan tetapi juga sebagai bentuk pegabdian kepaada Tuhan. Konsep inilah yang memungkinkan pemimpin tersebut berlaku dengan seadil-adilnya dan penuh dengan keikhlasan.

Perihal nilai karakter religius, sebenarnya di negara Indonesia sudah dijadikan pandangan hidup bangsa, yakni tercantum dalam Pancasila sila ke-1 Ketuhanan Yang Maha Esa. Makna Ketuhanan ini adalah bahwa bangsa Indonesia mengakui bahwa negara berdasarkan nilai-nilai Ketuhanan. Nilai-nilai ini pedoman dasar dalam kehidupan berbangsa dan bernegara. M.S, Kaelan (2010) menjelaskan bahwa dalam konsep Pancasila sebagai sistem, maka sila ke-1 Ketuhanan Yang Maha Esa harus menjiwai dan mendasari sila-sila yang lainnya. Hal ini sesusia dengan teori Hierarkis Piramidal Pancasila. Misalnya sila kedua Kemanusiaan yang Adil dan Beradab dijiwai dan didasari oleh konsep Ketuhanan. Oleh karena itu, kemanusiaan dan keberadaban kita merupakan rahmat dari Tuhan ynag Maha Kuasa yang harus senantiasa dijaga, dirawat, dan dilestarikan. Dalam perspektif keriafan lokal, nilai religius menjadi sangat penting sehingga menjadi dasar dalam setiap kehidupan mereka. seperti yang dijelaskan dalam hasil penelitian Sukmayadi, T (2016) di masyarakat adat Kampung Kuta, bahwa nilainilai kearifan lokal yang yang dianggap sebagai dasar atau fondasi adalah nilai religius yang dalam hal ini percaya kepada Tuhan Yang Maha Kuasa dan arwah para leluhur. Oleh karenanya, mereka tidak berani untuk melanggar segala ketentuan Tuhan dan warisan para luluhur.

Persepsi masyarakat adat Kampung Cireundeu dan Cikondang tentang nilai-nilai karakter yang harus dimiliki oleh seorang pemimpin jikalau dikaji dalam konteks Hierarkis Piramidal Pancasila (M.S, Kaelan. 2010), maka yang menjadi pusat sentralnya adalah nilai religius. Nilai ini kemudian mendasari nilai-nilai karakter berikutnya yakni taat kepada adat dan tradisi leluhur, dan taat pada falsafah sunda, yakni silih asih, silih asah, dan silih asuh

Selain berpersepsi tentang nilai-nilai karakter yang harus dimiliki oleh seorang pemimpin, masyarakat adat Kampung Cireundeu dan Cikondang juga berpersepsi tentang makna nilai-nilai karakter tersebut bagi kehidupan bermasyarakat. Adapun makna nilainilai tersebut adalah sebagai fondasi dalam membangun kehidupan masyarakat sesuai adat dan tradisi leluhur. Fondasi dalam sebuah 
bangunan merupakan hal yang paling utama, sebab jikalau fondasinya lemah maka bangunan tersebut akan roboh, begitu juga sebaliknya, jikalau fondasi itu kuat, maka bangunanpun akan kuat. Oleh karenanya, setiap fondasi dalam sebuah bangunan mesti terbuat dari bahan yang paling kuat diantara bahan-bahan bangunan lainnya. Begitupun di masyarakat adat, sesuatu dianggap fondasi atau dasar, maka mesti sesuatu tersebut dianggap bernilai yang sangat tinggi. Kedudukan nilai-nilai karakter yang harus dimiliki seorang pemimpin pada masyarakat adat, yakni sebagai fondasi dalam kehidupan bermasyarakat, maka fondasi yang paling utama ialah fondasi religiusitas yakni falsafah dasar dalam meyakini keberadaan Tuhan Yang Maha Kuasa sebagai yang Maha Pencipta yang patut dipuja dan disembah. Oleh karenanya, sebetulnya karakter religius ini tidak hanya untuk pemimpin saja, akan tetapi juga untuk semua masyarakat.

\section{SIMPULAN}

Kepemimpinan pada masyarakat adat pada dasarnya dilandasi oleh persepsi masyarakatnya yang kuat terhadap makna nilai-nilai karakter yang harus dipunyai oleh seorang pemimpin. Hal ini menguatkan paradigma bahwa seorang pemimpin akan dipengaruhi oleh lingkungan masyarakatnya, karena pemimpin dilahirkan dari suatu masyarakat tersebut. 


\section{DAFTAR PUSTAKA}

Atriana, R., 2016. ICW: 500 Orang Jadi Tersangka Kasus Korupsi Sepanjang Januari-Juni 2016. [Online] Available at: https://news.detik.com/berita/3285348/icw-500-orang-jadi-tersangkakasus-korupsi-sepanjang-januari-juni-2016 [Diakses 15 Mei 2017].

Asrori, Mohammad. (2009). Psikologi Pembelajaran. Bandung: CV Wacana Prima.

Elfira. M. (2013, 13-14 Juni). Model Kepemimpinan pada Lembaga Pemerintahan Berbasis Kearifan Lokal di Minangkabau dan Bugis. Paper presented at International Conference On Indonesian Studies Ethnicity and Globalization. Fakultas Ilmu Pengetahuan Budaya, Universitas Indonesia. Depok.

Fatimah, S. 2001. Kepemimpinan Tradisional Masyarakat Minangkabau pada Masa Pendudukan Jepang. Jurnal Tingkap Vol. VII No. 1 Th. 2011. Hal: 75-88. Padang: Pusat Kajian Sosial Budaya dan Ekonomi (PKSBE), Kampus FIS UNP Padang.

Kamus Besar Bahasa Indonesia Dalam Jaringan (Daring).

M.S, Kaelan. (2010). Pendidikan Pancasila. Yogyakarta: Paradigma.

Marpaung, Marudut. (2014). Pengaruh Kepemimpinan dan Team Work terhadap Kinerja Karyawan di Koperasi Sekjen Kemdikbud Senayan Jakarta. Jurnal Ilmiah Widya Vol.2, No.1. Hal: 35-36. Jakarta: STIE Dharma Bumiputra Jakarta.

Nazir, Moh. 2005. Metode Penelitian. Jakarta: Ghalia Indonesia.

Robbins, S.P. (1996). Perilaku Organisai: Konsep, Kontroversi, aplikasi, edisi Bahasa Indonesia. Jakarta: PT. Prenhalindo.

Ruyadi, Yadi. 2010. Model Pendidikan Budi Pekerti Berbasis Budi Pekerti (Penelitian terhadap Tradisi Masyarakat Adat Kampung Benda Kerep Cirebon Provinsi Jawa Barat untuk Mengembangkan Pendidikan Budi Pekerti di Sekolah). Disertasi Doktor pada SPS UPI Bandung: tidak diterbitkan.

Satori, D. dan Aan Komariah. (2011). Metodologi Penelitian Kualitatif. Bandung: Alfabeta. 
Slameto. (2010). Belajar dan Faktor-faktor yang Mempengaruhinya. Jakarta : Rineka Cipta.

Sondang. P. Siagian. 2011. Manajemen Sumber Daya Manusia. Jakarta: Bumi Aksara. Jakarta.

Sukmayadi, T., 2016. Kajian tentang Karakter Berbasis Nilai-Nilai Kearifan Lokal (Studi Kasus pada Masyarakat Adat Kampung Kuta Kecamatan Tambaksari Kabupaten Ciamis). Jurnal Civics (Media Kajian Kewarganegaraan), Jurusan Pedidikan Kewarganegaraan dan Hukum FIS Universitas Negeri Yogyakarta, Volume 13, p. 96.

Thoha, M. (2010). Kepemimpinan Dalam Manajemen. Jakarta: Raja Grafindo Persada.

Wahjosumidjo, (1999). Kepemimpinan Kepala Sekolah: Tinjauan Teoritik dan Pemasalahannya. Jakarta: PT. Raja Grafindo Persada. 